\title{
VISIONS OF AZTLÁN: THE CHICANO DOCUMENTARY FILM
}

\author{
David R. Maciel \\ Centro de Investigación y Docencia Económicas (CIDE), México
}

\begin{abstract}
In the decade of the 1960s and 1970s, a trascendental social movement -which was known as the Chicano Movement for Civil Rights- took place in the United States. One of its major achievements was a cultural flowering that encompassed all the art forms and practices. Among them, one of single importance is the documentary film. This article presents an overview of the origins, first steps and current developments of the Chicana/o documentary cinema. Such films address a multitude of topics and combine highly artistic value with a definite political message. In addition, the Chicana/o documentary is an outstanding and highly informative mirror into Chicano experience. Since its inception to the present, over 100 documentaries have been produced and exhibited in the US, yet they have not been well-distributed in the Spanish-speaking world.
\end{abstract}

Keywords: Chicano Movement, Chicana/o Documentary Cinema, Genesis and Stages, Evolution, Directors.

\author{
VISIONES DE AZTLÁN: \\ EL FILME DOCUMENTAL CHICANO
}

\section{RESUMEN}

En las décadas de los 1960s y 1970s, un movimiento social trascendental -conocido como el Movimiento Chicano por los derechos civiles- tuvo lugar en Estados Unidos. Uno de sus grandes logros fue el florecimiento cultural que incluyo todas las formas y prácticas artísticas. Este artículo presenta una panorámica de los orígenes, primeros pasos y desarrollos recientes del cine documental de Chicanos y Chicanas. Estas cintas se refieren a múltiples temas y combinan un alto valor artístico con un contundente mensaje político. Además, los documentales realizados por Chicanos y Chicanas constituyen un espejo extraordinario y muy informativo sobre la experiencia Chicana. Desde sus orígenes hasta el presente más de 100 documentales se han producido y exhibido en EE. UU.; sin embargo no han sido bien distribuidos en el mundo de habla hispana.

Palabras Clave: movimiento chicano, cine documental chicano/a, génesis y etapas, evolución, directores. 
For Jesús Salvador Treviño and Héctor Galánexemplary filmmakers and cultural promoters.

\section{INTRODUCTION}

The Mexican-origin population in the United States (called here Chicanas/ os) is currently made up of 36.6 million people, according to the Census Bureau, ${ }^{1}$ which makes it the largest national minority in numerical terms in the United States. Its population growth is quite extraordinary with experts pointing out that it is almost doubling in number every forty years. This community is also well known for being geographically dispersed throughout the US. Additionally, its members have become uniquely important and increasingly influential in all areas of American society: economic, political, social, and cultural. Chicanas/os, in fact, are changing the very fabric and essence of the country.

In the 1960s and 1970s, this community actively participated in a heroic social struggle for civil rights, known as the Chicano Movement (or La Causa). This social conflict was framed in the context of intense mobilizations from different sectors of American society (African Americans, women, indigenous peoples and young people), who demanded justice and social equality. Among its many achievements and legacy, La Causa fostered a cultural flourishing that included all artistic genres: letters, art, theater, music, and certainly cinematography. In this last field, the Chicana/o documentary film certainly stands out and its development has continued in a remarkable fashion from the time of intense activism in the 1960s and 1970 s to the very present (Maciel "El florecimiento, 82-86). During these decades, more than a hundred documentaries have been produced and exhibited, ${ }^{2}$ and this number increases each year. By now there are already three generations of Chicana/o filmmakers. ${ }^{3}$ Due to the diversity of its topics, it is more than evident that the documentary has been a primary source for the knowledge of the social, political and cultural experience of the Chicana/o people. Frequently, documentary filmmakers have addressed important issues that have even eluded the attention of specialists, bringing forth critical images and narratives to their artistry. Their works have had a profound impact on addressing the invisibility and the denigrating and negative stereotypes about the Chicana/o population, the latter being the norm in American cultural, visual and print expressions (Maciel and Racho 375-378).

1 See "US Census Bureau 2017 American Community Survey B03001 1-Year Estimates Hispanic or Latino Origin by specific origin.” https://factfinder.census.gov/faces/tableservices/jsf/ pages/productview.xhtml?pid=ACS_17_1YR_B03001\&prodType=table.

2 Personal interview with the filmmaker Héctor Galán (29 Aug 2020).

3 The author greatly appreciates that various Chicano documentalists have generously shared with him their time and experiences over the years: Isaac Artenstein, Nancy de los Santos, Paul Espinosa, Héctor Galán, Cristina Ibarra, Lourdes Portillo, Susan Racho, Rey Telles, Joseph Tovares and Jesús SalvadorTreviño among others. 
One main characteristic of these filmmakers is that they often serve as writers and producers as well as directors of their documentaries. Another essential premise is the increasing participation of Chicanas in this cultural practice. Nowadays, over a third of Chicana/o documentaries are produced, written or directed by Chicanas. ${ }^{4}$

It should be noted that the documentary as a film genre was defined by Scottish filmmaker John Grierson in 1926 as the "creative treatment" of a real situation that presents "life as it is" (Hardy 12-14), which certainly differentiates it from a fictional work. For his part, Bill Nichols points out that the protagonists of the documentary are people or social actors related to events that occurred in real life, and underlines how the documentary filmmaker gathers evidence to construct a story that becomes a way of observing the world. The director then develops his/her own style and with his/her team have important decisions to make: how to cut, edit or juxtapose images, how to frame and film each shot, what type of music accompanies the images, the possible presence of narrators and translators of testimonials; as well as the order of the presentation of events that can be chronological or not (Nichols 14; 34-35). Nichols also states that the documentary can help create a sense of community, especially in the face of adverse situations (p. 215). Adding to this last point, Jane Chapman affirms that the documentary is a discursive formation that uses images to inform creatively about different social problems (8).These points are most pertinent to the study of the Chicana/o documentary.Above all, Chicano documentaries have exemplified narratives that masterfully capture the two essential issues of the Chicana/o experience: on the one hand, the multiple practices of oppression, discrimination, harassment and violence that have been carried out against this community by the dominant society throughout its history. On the other hand, there is also the extensive and courageous trajectory of resistance-through multiple and very diverse efforts-to maintain their Mexicanness, language, identity and traditions, as well as their constant fight for their civil rights and for greater representation in politics, social life and cultural practices in the United States.

Nichols outlines a typology of documentaries, in which there exist certain modes that are crucial for an understanding of Chicana/o documentary cinema:

- Expository mode, where verbal comment and logical argumentation are emphasized (these are more traditional documentaries).

- Poetic mode, characterized by visual associations with descriptive passages that are typical of an experimental cinema.

- Observational mode, in which the participants of the documentary are filmed in their daily activities.

- Participatory mode, where the director interacts with the subjects of the documentary through conversations or interviews (31-32).

\footnotetext{
${ }^{4}$ Personal interview with the filmmaker Héctor Galán (29 Aug 2020).
} 
Documentaries from each of these categories have been brought to the screen encompassing the history of the Chicana/o and Latina/o communities, the current issues they are faced with, as well as selected themes related to Mexico and Latin America.

\section{GENESIS AND FIRST STEPS}

It was during the effervescence of the Chicano Movement that a first generation of Chicano documentary filmmakers emerged. They became the first filmic chroniclers of the events of their community. Most of them were university students who took to the streets with their Super 8 cameras, because they felt the prevailing need to film the strikes, demonstrations and other political actions carried out in the different facets of this extraordinary social conflict. Their pioneering film works captured on screen the intense energy, commitment, creativity and challenges that characterized La Causa (Treviño 54-68). The documentary was the film genre of choice for these incipient filmmakers, given that its cost was much lower than that of feature films, and at the same time it was the ideal medium for filming dayto-day scenes of the social struggle and other relevant issues that the community of Mexican origin faced. In addition, the development of the documentary was also due to the fact that it found ample spaces for its exhibition through university circles, community centers, art circuits, public libraries and-already in the 1970s and later-on television and through film festivals.

The list of Chicano documentaries grew at an impressive rate during its first stage (1966-1979), which runs parallel to the emergence of the Chicana/o Movement and the years after. Its extensive thematic range includes: Chicano history (deeply linked to Mexican history); the social and political struggles; gender issues; cultural practices; immigration issues and the US-Mexico border, among others (Maciel $E l$ bandolero, 142-56). All the documentaries clearly reflected the double commitment of Chicano filmmakers: to contribute works of high artistic value and to transmit a political discourse associated with the ideology of Chicanismo. The prominent director Jesús Salvador Treviño-activist and pioneer in the incursion of Chicanos in the media-clearly pointed out the relationship of Chicano filmmakers with the social context, in the following terms: "Chicano cinema must be clear in its denunciation of past and present brutalities and must go further: it must serve the needs of the community, reflect the beauty of our lifestyle, pave our way into the future [and] unite us with our common cause. Our art must be one of defense and support" (Treviño 68). Treviño was a major participant and chronicler of seminal events of the Chicano Movement, such as the farmworker strikes, the student demonstrations, the founding of the Chicano Youth Conference in Denver, the movement to recover lost lands in New Mexico, the Chicano Moratorium (against the Vietnam War) and the founding of the La Raza Unida Party.

In this early period, two films of pioneering directors-now considered classics-stood out: Yo soy Joaquin (1969) by Luis Valdez, and Yo soy Chicano (1971) by Jesús Salvador Treviño. Yo soy Joaquin has a unique aesthetics as it is based on 
the epic poem by Rodolfo "Corky" Gonzales, and has Luis Valdez as its narrator. The film reviews the historical roots of the Chicano and largely draws from preColumbian civilizations while intertwined with Mexican history. The central theme of the documentary is the formation of Chicano identity. Joaquín is not one person, but represents an entire race. The documentary was done in an artisanal fashion in a matter of a few weeks, as the director himself related. ${ }^{5}$ To date, it has become a cult film that is now part of the National Film Registry at the Library of Congress. The other major documentary, Yo soy Chicano, is divided into two segments: the first draws upon a concise and creative sketch of the historical development of the Chicano population, includes scenes with actors representing historical figures and, in general, offers a succinct narrative of the historical process(es) at play. The second segment contains interviews and chronicles about the iconic leaders of the Chicano Movement, such as Dolores Huerta, César Chávez, Rodolfo "Corky" Gonzales, José Angel Gutiérrez and Reies López Tijerina. Above all, this film beautifully captures the ethos of the Chicano Movement. Another great achievement of Yo soy Chicano is its musical score that adds a great deal to the images and narrative of the documentary.

These pioneering films were followed by numerous documentaries that reviewed both the Chicano Movement and the agendas of its leaders (Noriega 15288). Among them are: Strike (1965) by Luis Valdez on the union movement of César Chávez; Tijerina: Fighting for the Land (1968) by Paco Pérez on the leader Reies López Tijerina, who fought for the recovery of the land usurped by Anglos in New Mexico; Chicano Moratorium (1970) by Tom Myrdahl and Requiem-29 (1971) by David García on critical Chicano protests against the Vietnam War (the Chicano Moratorium); Si se Puede (1972) by Rick Tejada-Flores and Gayanne Fietinghof on César Chávez’s farmworker movement; as well as Raza Unida (1972) by Jesús Salvador Treviño and Cristal (1975) by Severo Pérez on the emergence and importance of the political party named La Raza Unida. In this first stage, there were pioneering Chicana documentary filmmakers who produced other important works. Esperanza Vázquez filmed Agueda Martinez: Our People Our Country (1977) that explores the essence of Northern New Mexico through the eyes of a weaver, who lives in great harmony with nature. In 1979, Sylvia Morales wrote and directed the documentary Chicana, which is an influential and pioneering reflection on the role of women from pre-Columbian times to the present. This film contains powerful imagery, historical narratives, and testimonies of Chicanas from the 1970s, women who discuss their achievements and lingering challenges (Leen 207-10).

In regard to the social problems of the Chicana/o community, various documentaries stand out: Soledad (1971) by Jesús Salvador Treviño addresses the plight of Chicano prisoners in the jail of the same name, and América Tropical by the same director documents the censorship of a mural painted by David Alfaro Siqueiros in Los Angeles; Cinco Vidas (1972) by José Luis Ruiz and Moctezuma Esparza recounts stories of Mexican-American characters living in East Los Angeles;

${ }^{5}$ Luis Valdez (lecture delivered at the Cineteca Nacional, Mexico City, 10 Aug. 2014). 
La Onda Chicana (1976) by Efraín Gutiérrez touches on rock music created in the community; and The Unwanted (1975) by José Luis Ruiz represents an exceptional analysis of the enormous contributions of Mexican migrants in the United States, thereby denouncing their exploitation and their treatment as criminals by the US immigration agencies. During this period, various Chicana/o documentalists (as well as fiction filmmakers) sought new paths toward greater professionalization and more substantial ways to finance their films. As never before, some directors participated in public and private television programs, such as Acción Chicano, Reflections, Realities and Unidos. Most of these programs were produced in California, although others were broadcasted in major cities, such as Chicago, New York and San Antonio (Noriega 160-61).

In addition, the support for Chicano filmmaking-el cine chicano-in terms of promotion and distribution came from various organizations, such as Carisma, Latino Consortium, National Latino Media Coalition and Chicano Cinema Coalition. Furthermore, around this time film festivals began, such as the Chicano Film Festival in San Antonio in 1975, which contributed to the widespread dissemination of new film works. Also, some filmmakers, such as Moctezuma Esparza, José Luis Ruiz, Severo Pérez, Jesús Salvador Treviño, Sylvia Morales and Lourdes Portillo began establishing their own production and distribution companies. This was the case with Moctezuma Esparza Productions in 1974, Ruiz Productions in 1975, Learning Garden Productions in 1976, New Vista Productions in 1977, and Sylvan Productions and Xóchitl Films in 1979. Their main objective was to seek greater control over the production and distribution of their tapes and, additionally, to diversify their funding sources, which combined donations from specialized groups and foundations with funds from both the public television network: the Public Broadcasting Service (PBS) (created by the Public Broadcast Service Act of 1967) and the US Department of Education (using funds allocated by the Bilingual Education Law of 1968) (Noriega 9-21).

\section{A MARVELOUS FLOWERING}

Generally speaking, all of these endeavors by Chicano documentalists became more difficult in the 1980s and early 1990s as a result of the shift to the political right in the United States during the republican governments of Ronald Reagan and George Bush. Both presidents were against the public financing of artistic expressions, especially those that were critical of the status quo and concerned with issues, such as racism and discrimination. Nonetheless, PBS continued to be a vital element in the expansion of the filming and broadcasting of Chicana/o documentaries. ${ }^{6}$ This entity gradually opened the doors to an affirmative action program that allowed the funding and national-level screening of Chicana/o

${ }^{6}$ On PBS, see, https://www.pbs.org/about/about-pbs/. 
documentaries as well as the attainment of the professionalization of Chicana/o filmmakers, who until then produced film with minimal resources. In fact, the Latino Public Broadcasting Service (LPB) was established in 1998, thanks to the advocacy of acclaimed actor Edward James Olmos, who was the founder of such an initiative and its first executive director. Since then, LPB has been in charge of providing considerable financial support for the filming of documentaries, which would later to be shown by PBS, the public television network in the United States.

PBS has become the cultural alternative to commercial television stations.

It has the advantage of being an integral part of the open television system, given that its access is free and does not require a cable or satellite subscription to view it. Through its three hundred and fifty affiliated stations across the US, PBS can reach an audience of up to one million people nationwide in a single night. For this reason, according to filmmakers, like Héctor Galán, audiences for Chicano documentaries far exceed the scope of Chicana/o feature films. ${ }^{7}$ In this scenario, the Chicana/o documentary had a time of exceptional flourishing from 1980 to 2000 in which artistic maturity and breadth of content came together. Both Chicanos and Chicanas contributed unique experiences and perspectives to their craft. They already belonged to two generations and came from various regions of the United States, consequently bringing different realities to the screen (Noriega 16-28). With great creativity, their films covered multiple themes on history, gender issues, immigration, contemporary problems of the Chicana/o and Latina/o communities, as well as topics related to Mexico and Latin America.

Lourdes Portillo is a pioneer director of valuable documentaries. In Las Madres: The Mothers of the Plaza de Mayo (1985), she depicts a seminal woman's organization that was in the front line, denouncing the excesses in human rights violations committed by the brutal Argentine dictatorship. This film was nominated for an Oscar for Best Documentary in 1986. La Ofrenda: The Days of the Dead (1988) is a film that explores the tradition of honoring the dead in Mexico, and how this tradition has been transplanted into the United States. Corpus: A Home Movie for Selena and Conversations with Intellectuals about Selena (both from 1999) refer to the famous Chicana singer of the same name who tragically died at the age of 24, having achieved great popularity inside and outside the US. The first film deals with her personal and professional life, and the second brings to the screen a discussion among Chicana intellectuals about Selena as a cultural icon and as a role model within the community.

Other Chicana documentary filmmakers also made important contributions. Nancy de los Santos ventured into the complex issue of migration in Port of Entry (1981). The film focuses on the story of an immigrant family, who moves from Mexico to the Pilsen neighborhood of Chicago; it highlights not only the multiple challenges faced in the US, but also its contributions to its destination community. Beverly Sánchez Padilla directed El corrido de Juan Chacón (1983), a famous Chicano

\footnotetext{
Personal interview with the filmmaker Héctor Galán (11 Dec 2016).
} 
union leader from the 1950s in New Mexico, who played a crucial role in the dramatic strike portrayed in the cult film The Salt of the Earth (1954). Sylvia Morales produced the documentary AIDS Is AIDS (1989) about the impact of this terrible disease on the Chicana/o community (Fregoso Lourdes Portillo, 34-36). Another of her films, De mujer a mujer (1993), focuses on the bearing of sexual violence against Chicana women in South Texas. In 1997, Laura Angélica Simón, an elementary school teacher from Los Angeles, filmed Fear and Learning in Hoover Elementary. It was an extremely revealing documentary about the anti-immigrant environment in schools, a filmic event that received a great deal of positive critical reviews.

At this stage of the Chicana/o documentary, filmmakers such as Héctor Galán stood out. He became a prolific filmmaker in this genre, given that his films were characterized by great thematic originality and artistic quality. Los Mineros: The Miners (1991), written by Paul Espinosa, narrates the Chicano labor struggle in Arizona copper mines (1903-1946), which had a profound influence on the history of the Mexican-American community in that state. The Hunt for Pancho Villa (1993), produced and written by Paul Espinosa, addressed a controversial chapter in the Mexico-United States relationship: the failed US military incursion (the Pershing Expedition) into Mexican territory in order to capture General Francisco Villa during the Mexican Revolution of 1910.

Producer/writer/director Paul Espinosa contributed to other important films in various capacities. ${ }^{8}$ As a director, in The Lemon Grove Incident (1985), he focused on the mobilization of a community against institutionalized discrimination in a school district near San Diego. In addition, he filmed documentaries on key aspects of the Mexico-United States relationship. This was the case of Uneasy Neighbors (1989) and The New Tijuana (1990), which focus on major border issues between the two countries. Also, in The US-Mexican War (1998), director Espinosa addressed the 1846-1848 conflict that resulted in the loss of 51\% of Mexico's territory (which became the southwestern part of the United States), and certainly changed the destiny of both countries and led to the emergence of the Chicana/o community that remained in el Mexico perdido (Maciel El bandolero, 150-56). Other documentaries highlighted several notable episodes in 20th century Chicano/Mexican history. The Ballad for an Unsung Hero (1983) by Paul Espinosa as producer/writer and directed by Isaac Artenstein recounted the story of Pedro J. González, who became the first celebrity of Spanish-speaking radio in the US in the late-1920s and during the Great Depression years. Another film, After Joaquin: The Crusade of Justice (1985) by Daniel Salazar et al., dealt with key aspects of the life of the leader of the Chicano Movement, Rodolfo "Corky" Gonzales. The Struggle in the Fields (1997), by Ray Telles and Rick Tejeda-Flores, chronicled the plight of the agricultural workers led by César Chávez by using narratives, interviews and actual footage of critical aspects of the movement. And Pancho Villa \& Other Stories (1999) by Phillip Rodríguez

\footnotetext{
${ }^{8}$ Personal interview with the filmmaker Paul Espinosa.
} 
narrated popular views on the famous general of the Mexican Revolution, Francisco Villa (Maciel La otra cara, 354-55).

Among the documentaries of the late-twentieth century, the masterful series Chicano! History of the Mexican-American Civil Rights Movement (1996) occupied a very prominent place. The film was sponsored by PBS with José Luis Ruiz and Jesús Salvador Treviño as co-Executive Producers. They hired Héctor Galán as the supervising series producer and the episode producers were Susan Racho, Mylène Moreno and Sylvia Morales. ${ }^{9}$ This four-episode series is the most comprehensive and ambitious documentary on the significance of the Chicano Movement and its legacy. Its narrative powerfully and artistically captures the development of the Chicano Movement from 1965 to 1975, as well as the main agendas and achievements of its iconic leaders, including César Chávez, Dolores Huerta, Reies López Tijerina, Rodolfo "Corky" Gonzales and José Angel Gutiérrez. Prominent filmmakers participated in the writing of the script and in the direction of its four parts, including Héctor Galán, Sylvia Morales, Mylène Moreno, Susan Racho, José Luis Ruiz and Jesús Salvador Trevińo. In the making of this series, four renowned academics served as advisers to the filmmakers. ${ }^{10}$ Upon acknowledging the enormous importance of this series, what remains is that a similar film endeavor about the many achievements and challenges of the Chicana/o community in the new millennium is very much pending.

\section{CONSOLIDATION AND SPLENDOR}

In the new millennium, the Chicana/o documentary has had a prodigious development in terms of its growing number of films and their high artistic quality and creativity. It has also continued addressing diverse topics related to history, culture, gender issues, social policies, politics and immigration, among others. This process has continued to the very present, making the documentary the dominant genre of el cine Chicano. The most recent Chicano documentaries-of at least three generations-still embody the double purpose of offering works of high artistic value, while integrating strong political messages of ethnic pride. The fine-tuning of financing and exhibition mechanisms has brought the Chicana/o documentary to its prime. It is important to note that the funding and wide distribution provided by PBS and its Latino arm, the LPB, have been crucial to its continued blossoming. ${ }^{11}$ Moreover, independent films have been produced and later on distributed in art and university cinema circuits. This is the case of several documentaries financed

9 Personal interview with the director Jesús Salvador Treviño (14 Sept 2020).

${ }^{10}$ See Francisco A. Rosales, Chicano!: The History of the Mexican American Civil Rights Movement (1996). This is a synthesis of the topic of the series History of the Mexican-American Civil Rights Movement.

${ }^{11}$ Personal interview with Luis Ortiz (a high-ranking official of Latino Public Broadcasting). See also Latino Public Broadcasting (2020). 
since the late 1990s by the Center for Regional Studies at the University of New Mexico. One of its most ambitious documentary projects was Colors of Courage: Sons of New Mexico (2002) by Paige Martínez, which recounts how during World War II thousands of US and Filipino soldiers were captured in Bataan, the Philippines, by the Japanese and forced to perform the "death march" towards a prison camp. Among them was a battalion of soldiers of about 2,000 members-the vast majority of them Chicanos from New Mexico-who suffered abuse and many of them died. This tragic event was later considered a war crime.

Chicana filmmakers have also significantly contributed to the development of el cine Chicano during the two decades of the present millennium. Lourdes Portillo has produced key documentaries. For example, Señorita Extraviada: Missing Young Woman (2001) is a shocking, groundbreaking film about the terrible tragedy of the ruthless femicides of more than three hundred and fifty women that have been committed in Ciudad Juárez, the most violent city of Mexico at that time. This film collects insightful and moving testimonies, while exploring the root causes of such horrendous gender violence. The same prolific director examines the realities of drug trafficking in the broader Mexican-Caribbean region in Al Más Allá (2008), a film that includes interviews and her own narrative. In Night Passages (2013), director Portillo deals with an autobiographical reflection on her experience with the diagnosis and treatment of cancer. ${ }^{12}$ Other Chicanas depicted key women's issues in their documentaries. Sylvia Morales in Crushing Love (2009) reviews the personal history of five notable Chicana activists, highlighting their contributions to empower the lives of other women: Dolores Huerta, Elizabeth "Betita" Martínez, Cherríe Moraga, Alicia Escalante and Martha Cotera (Leen 212-13).

Cristina Ibarra develops various films related to the complexity of the transboundary links in the US-Mexico border. The Last Conquistador (2008), co-directed/co-produced with John J. Valdez, traces the great controversy that divided people in the city of El Paso, Texas, around the building of a statue of the Spanish conqueror Juan de Oñate. In Las Marthas (2014), this director addresses the story of a group of young Chicanas in Laredo, Texas, that are changing a traditional American celebration by introducing Chicana/o and Mexican cultural traits. With great creativity, Ibarra ends up generating an insightful reflection on complex social and cultural interactions that occur at the border. ${ }^{13}$ In The Infiltrators (2019), Cristina Ibarra along with Alex Rivera follow the story of two Dreamers, ${ }^{14}$ who narrate their experiences of having been incarcerated in one of many US "private prisons," where

12 See The Films and Videos of Lourdes Portillo (2016).

13 See Las Marthas (2013).

${ }^{14}$ At one point, Deferred Action for Childhood Arrivals (DACA) allowed more than 700,000 youth (who met certain requirements) to legally reside in the United States-the Dreamers. These young people were brought in their childhood or adolescence by their undocumented parents from Mexico, but also from other countries in Latin America and around the world. Many of them were college graduates, ready to start their careers and contribute to the future of the US. The Trump administration has done everything possible to end DACA. So far, the immigration authorities have 
undocumented individuals are routinely sent. Currently, director Ibarra is working on a documentary about El Paso in the era of the COVID-19, a film that according to her own words: "traces, step by step, a portrait of a place with deeply complex bicultural roots." 15

A most prominent documentary is the impressive collective work, The Bronze Screen: 100 years of the Latino Image in Hollywood (2002), by Nancy De Los Santos, Susan Racho and Alberto Domínguez. It recreates images and clips from the original films, the negative representation and stereotypes of Latinas/os-the vast majority of them Chicanas/os-in Hollywood cinema from the silent era to the 1990s. This documentary contains incredibly valuable interviews with prominent Chicana/o and Latina/o actors and actresses such as Katy Jurado, Rita Moreno, Lupita Tovar, Ricardo Montalbán, and Anthony Quinn, among others, who offer key insights into their experiences in Hollywood. In addition, The Bronze Screen had the virtue of including four of the most renowned specialists in Chicana/o Film Studies as advisors in the making of its script: Rosa Linda Fregoso, David R. Maciel, Chon Noriega and Charles Ramírez-Berg.

When reviewing the documentaries of the new millennium, a unique, ambitious series must be highlighted: Latino Americans (2013). ${ }^{16}$ Adriana Bosch was the Series Producer with the key participation of other Producers: Nina Alvarez, Dan McCabe, Ray Telles and John Valadez. This monumental series that includes a three-part, six-hour documentary is particularly illustrative of the highly artistic and political commitment of Chicana/o and Latina/o filmmakers. The series narrates critical aspects of the origins and development of the four principal Latina/o communities in the United States: Chicana/o, Cuban-American, Puerto Rican, and recently Central American from the 16th century to the 2000. The series, the first in depicting Latina/o issues in a comprehensive format, received (when showed) the largest Latina/o viewing audience in PBS history. This excellent series depicts the demographic growth of these communities and their increasing participation and influence in all aspects of American society, politics and culture. Its ultimate purpose was to demonstrate the similarities as well as the singularities of each of the four major Latina/o populations in the United States. An important point is that this series supports what academic studies have already documented: the transcendental significance of the process of "Latin Americanization" of the United States that is definitely changing forever the profile and future of the US. ${ }^{17}$ Nancy de los Santos along with Dan Guerrero produced Lalo Guerrero: The Original Chicano (2006), which recalls critical episodes of Chicana/o cultural history of the 20th century through the life of this extraordinary singer and prolific composer of all kinds of genres and musical themes. For his decade-long career, Lalo Guerrero

stopped receiving new applications for DACA. See, Caitlin Dickerson, "What is DACA and Why Did It End Up in the Supreme Court of the United States?".

${ }^{15}$ See Cristina Ibarra Films \& Work in Progress (2020).

16 See Latino Americans (2013).

17 Personal interview with the director Ray Telles. 
became a famous and influential artist in the United States as well as in Mexico, where he achieved fame with his very popular children's album Las ardillitas (1958). Ultimately, this documentary reflects on the great transboundary legacy that Lalo Guerrero left in Mexico and the US.

In 2011, Ray Telles filmed The Storm that Swept Mexico, which constitutes an impressive, diligent and unique interpretive discussion of the history of Mexico from the prelude to the 1910 Revolution and into the 1990s. This excellent documentary is divided into two segments; one covers a time span from the origins of the Mexican Revolution to its consolidation in the late-1930s, while the other segment focuses critically on Mexico's neoliberal reforms of the 1990s. ${ }^{18}$ The documentary illustrates the development of Mexico through most of the 20th century. It offers an insightful analysis by skillfully interweaving actual historical footage with interviews with Mexican participants in all of these events as well as well-known specialists.

The notable directors Héctor Galán and Jesús Salvador Treviño continued to increase their outstanding filmography in the recent period. Galán produced and directed another of his innovative works: The Children of Giant (2015). With inordinate sensitivity, the film shows the discrimination and oppression of Chicanas/ os in South Texas in the 1940s and 1950s. The documentary is principally based on dramatic episodes of the epic production Giant (1956) by George Stevens. This remarkable Hollywood film was unique in addressing the theme of institutional racism in Texas society. Galán also filmed Willie Velázquez: Your Vote is Your Voice (2016) about the founder of the Southwest Voter Registration and Education Project, an important and successful organization created for the fostering of civic culture. Velázquez became a titan in the promotion of political participation and the voting rights of the Chicana/o and Latina/o community throughout the Southwest. Veteran filmmaker Jesús Salvador Treviño continued augmenting his filmography. He directed, for example, innovative documentaries in the last decades. In the film In Search of Aztlan (2004), which was broadcasted on PBS in Los Angeles, he intercuts historians and scholars commenting on the historical and mythical concept of Aztlán with comedy drama from the group Culture Clash. ${ }^{19}$ In Visiones de Aztlan (2010), he delves into the meaning and development of Chicana/o art in the decades of the 1960s and 1970s. The film includes the testimonies of more than twenty prominent Chicana/o artists. In 2012, Treviño founded Latinopia, an imaginative and pioneering website dedicated to Chicana/o and Latina/o topics. In the case of film, the site projects five-minute mini-documentaries on his interviews with noted Chicana/o filmmakers, such as Héctor Galán, Myléne Moreno and John J. Valadez. ${ }^{20}$ Among the documentaries of the most recent years, there are several that refer to the Chicana/o social struggle. In Zoot Suit Riots (2014), director Joseph Tovares explores the context of racial tension in Los Angeles in 1943 that culminated

\footnotetext{
${ }^{18}$ See, The Storm that Swept Mexico (2020).

19 Personal interview with the director Jesús Salvador Treviño (31 Aug 2020).

20 See, Latinopia (2020).
} 
in terrible episodes of racism and violence against young Chicanos and Chicanas (the zoot-suiters) at the hands of members of the US Navy, who literally went out to "hunt them down." ${ }^{21}$ In Adiós Amor: The Search for Maria Moreno (2017), Laurie Coyle refers to the somewhat forgotten woman leader of the rights of migrant workers, who preceded the struggle of César Chávez and Dolores Huerta. Paul Espinosa, in Singing our Way to Freedom (2018), depicts the story of Ramón "Chunky" Sánchez and his musical contributions carried out during the Chicano Movement. In The Unafraid (2018), Heather Courtney and Anayansi Prado portray the story of three young undocumented people, who came out of their forced invisibility to become activists in favor of immigration reform in the US. Their efforts came to fruition during the Barack Obama administration with the approval of the Deferred Action for Childhood Arrivals (DACA) program that granted temporary residence to the Dreamers, permitting them the continuation of their studies and to work legally.

The prolific and creative filmmaker Philip Rodríguez probed into critical themes in important documentaries produced for PBS. For example, Mixed Feelings: San Diego/Tijuana (2002) contrasts the material conditions and attitudes of the people in both border cities. In addition, Los Angeles Now (2004) showcases the "Latin Americanization" of Los Angeles, considering it as a prelude to what will also happen in the US in the years to come. Brown is the New Green: George Lopez and the American Dream (2007) examines how the mass media has shaped the Latina/o identity, highlighting the story of an influential entertainer. Latinos '08 (2008) and RACE 2012 (2012) explore the role of Latinas/os in US politics in general and in the electoral processes of such years in particular..$^{22}$ Rubén Salazar: The Man in the Middle (2014) portrays the career and tragic death of this journalist writing for Los Angeles Times. And, The Rise and Fall of the Brown Buffalo (2018) narrates the life and influential work of the controversial and enigmatic lawyer, novelist and social fighter of the peak era of the Chicano Movement, Oscar Zeta Acosta (Hernández E8).

Professor, producer, writer and director John J. Valadez has consolidated his career through his extensive filmography on Chicana/o and Latina/o issues in the new millennium. In 2003, he was the producer of the PBS series Visiones: Latino Arts and Culture, a pioneer and panoramic view of major cultural trends and perspectives. In 2008, he was the co-director and co-producer of The Last Conquistador (along with Cristina Ibarra) about a controversial statue of the Spanish conqueror Juan de Oňate in El Paso, Texas. In 2010, in The Longoria Affair, Valadez addresses the contentious relationship between President Lyndon B. Johnson and the MexicanAmerican leader Héctor P. García on the question of forging civil rights for this population. In 2013, he filmed Prejudice and Pride dealing with the Chicano Civil Rights Movement, part of the monumental series Latino Americans. More recently, his film, The Head of Joaquin Murrieta (2016) deals with the story of this Chicano "social bandit," who ended up being decapitated in 1853 by the US authorities.

21 See, Zoot Suit Riots Gallery (2020).

22 See, About Philip Rodriguez (2020). 
The film narrates a search to locate and bury the head of Murrieta, but ultimately provides a view from the Chicano historical perspective of this legendary activist, his time and his plight.

Other recent documentaries produced by PBS address a variety of additional themes of the Chicana/o and Latina/o community. The Pushouts (2018) by Dawn Valadez retells the story of Professor Víctor Ríos, a Mexican migrant who was originally a gang member, but who turned his life around. He ultimately dedicated himself to helping adolescents expelled from schools, guiding them onto the right path. And, Harvest Season (2019) by Bernardo Ruiz chronicles the stories and problems of small producers and workers in the wine industry of Northern California, whose tasks and contributions are essential to the state economy, but are practically invisible to the Anglo community in the area. ${ }^{23}$

In 2020, Latino Public Broadcasting and PBS announce various new films, ${ }^{24}$ which means that these entities continue to be crucial for the funding, distribution and exhibition of Chicano documentaries. Building the American Dream (2019) by Chelsea Hernández deals with the real estate boom in Texas, derived from the exploitation of immigrants employed in the construction of luxury buildings. The film also narrates the immigrants' heroic efforts to improve their situation. ${ }^{25}$ Siqueiros: Wall of Passion (2019) by Lorena Manríquez depicts the highly symbolic value for the Chicana/o and Latina/o community for the rebirth of the mural "American Tropical" of the famous muralist David Alfaro Siqueiros, a work of art that was censured and partially destroyed by local authorities. Time of the Phoenix: The First Rainbow Coalition (2019) by Ray Santiesteban recounts an unknown story from 1969 of how the Chicago Black Panther Party intended to create political alliances with other local groups, including Chicanos. Finally, in a critical electoral year in the United States, VOCES: Latino Vote; Dispatches from the Battleground (2020) by Bernardo Ruiz chronicles the efforts of activists and community organizations to promote the registration among Latinas/os entitled to vote in key states: Florida, Nevada, Pennsylvania and Texas. An interesting phenomenon in Chicana/o documentary filmmaking is that non-Chicana/o filmmakers have made important documentaries on critical themes of the Chicana/o and Latina/o communities. There exist various examples of this trend in this new millennium. Academic and filmmaker Joanne Hershfield, in Nuestra Comunidad: Latinos in North Carolina (2001), collects insightful testimonies from the fairly unknown experience of members of the growing Mexican and Latina/o immigrant community in North Carolina. Jordan Mechner produced and directed Chávez Ravine: A Los Angeles Story (2004). The film gives an account of the unjust eviction of three hundred families from the Chávez Ravine area of Los Angeles in the 1950s (as a pretext in the process

of gentrification, but which served to establish Dodgers Stadium) without receiving

${ }^{23}$ See Trailer. The Pushouts. (2020); and Stream Harvest Season (2020).

${ }^{24}$ See Latino Public Broadcasting (2020).

25 See Building the American Dream (2020). 
any compensation for their valuable land and the destruction of their property. In addition, Peter Bratt directs Dolores (2017), an award-winning documentary that traces the heroic life of the Chicana leader Dolores Huerta, who at ninety years old continues with her intense activism. This documentary faithfully captures the lifetime devotion of the noteworthy social activist to larger causes and how she has become a true icon for the Chicana/o community as well as a source of inspiration for contemporary social movements. ${ }^{26}$

In They Called Me King Tiger (2017), director Ángel Estrada Soto and producer Inti Cordera depict the exceptional life of the Chicano leader Reies López Tijerina and his plight for the recovery of the lands lost by Mexicans/Chicanos in New Mexico after the war between Mexico and the US. These two Mexican filmmakers made a valuable contribution by extensively interviewing Tijerina. In fact, this film captures the famed activist's own testimonies about his outstanding activist career and provides the last images of this charismatic icon of the Chicano Movement. The documentary, without a doubt, will become an invaluable tool for future scholars and writers interested in investigating the contributions and legacy of Reies López Tijerina.

Another notable effort is Porvenir (2019). This is a documentary directed by Andrew Shapter and produced by Héctor Galán. It examines a most tragic episode in Chicana/o history. In 1918 in Porvenir, a small Texas town near the Mexican border, the infamous Texas Rangers murdered more than a dozen Mexicans without any cause and with total impunity. ${ }^{27}$ This incident was part of the hundreds of others that occurred against the population of Mexican-origin in the so-called "killing fields in Texas." In fact, historians William Carrigan and Clive Webb documented in their recent books that more than five thousand cases of Mexicans/Chicanos were victims of extreme, institutionalized violence in the American Southwest from 1848 to 1928, particularly in Texas (De Carrigan \& Webb 179-238).

\section{CONCLUSION}

It is undeniable that the Chicana/o documentary is one of the most outstanding and innovative cultural manifestations of the community of Mexican origin in the United States, both in terms of its artistic value and visual practice as well as its ability to interpret and analyze the Chicana/o experience. Its thematic variation and the fact that Chicana/o documentary filmmakers have well-incorporated all the categories of this film genre is noteworthy. Furthermore, it is evident that the Chicana/o documentary is a terrific source for the community to know and reflect on itself, including its history, culture and contemporary issues. In addition, these outstanding films have showcased the richness of its cultural practices to many

\footnotetext{
${ }^{26}$ See Me llamaban King Tiger (2019); and Dolores (2018).

${ }^{27}$ See Porvenir Massacre (2020).
} 
audiences both within and outside the United States. The fact that current generations of Chicana/o college students are on the rise and that many specialize in visual arts ensures that the Chicana/o documentary has an extremely promising future. Furthermore, there are still many Chicana/o historical and contemporary themes, episodes and characters pending to be addressed and examined. The co-sponsorship of PBS and LPB, and the founding of Chicana/o production companies (such as Galan Inc.) have opened up new possibilities for the financing and exhibition of documentaries in the near future.

In addition, it would not only be desirable, but also imperative to have broader dissemination and discussion of the Chicana/o documentary, including a concentrated effort for lobbying in terms of financing, distribution and exhibition by different governmental and non-governmental educational and cultural institutions, as well as digital platforms. Undoubtedly, documentary filmmakers would clearly support these important tasks. If better disseminated, the historical experience and growing importance of this population would be fully acknowledged for all its worth. As director Lourdes Portillo states: "we have been struggling for a long time, we have our history and we've fought it in our way, as the films speak to that." 28

REVIEWS SENT TO AUTHOR: 12-6-2020; REVISED PAPER ACCEPTED FOR PUBLICATION: 12-9-2020

${ }^{28}$ Personal interview with director Lourdes Portillo (11 Sept 2020). 


\section{WORKS CITED}

About Philip Rodriguez (2020). Philip Rodriguez. https://www.philliprodriguez.co/about.

Accessed 30 Aug. 2020.

Building the American Dream (2020). Ford Foundation et al. http://www.buildingtheamericandream. com/about. Accessed Aug. 302020.

Chapman, Jane. Issues in Contemporary Documentary. Polity Press, 2009.

Cristina Ibarra Films \& Work in Progress (2020). Cristina Ibarra http://www.cristinaibarra.com/. Accessed 28 Sept. 2020.

De Carrigan, William and Clive Webb. Forgotten Dead: Mob Violence against Mexicans in the United States, 1848-1928. Oxford UP, 2017.

Dickerson, Caitlin. “¿Qué es DACA y porqué terminó en la Corte Suprema de Estados Unidos?” The New York Times (18 June 2020) https://www.nytimes.com/es/article/daca-que-es.html. Accessed 3 Sept. 2020.

Dolores (2018). PBS Independent Lens. http://www.pbs.org/independentlens/films/dolores-huerta/. Accessed 15 May 2020.

Fregoso, Rosa Linda. Lourdes Portillo: The Devil Never Sleeps and Other Films. U of Texas P, 2001.

Fregoso, Rosa Linda. The Bronze Screen. U of Minnesota P, 1993.

Hardy, Forsyth. Grierson on Documentary. U of California P, 1966.

Hernández, Daniel. "Finding His Story in Theirs.” Los Angeles Times (23 Aug. 2020): E8.

KInG, Susan "Classic Hollywood: 'Children of Giant' explores legacy of 'Giant' in Marfa, Texas, 11 April, 2015. https://www.latimes.com/entertainment/classichollywood/la-et-mn-ca-classichollywood-children-giant-20150412-story.html. Accessed 28 September 2020.

Latino Americans (2013). PBS http://www.pbs.org/latino-americans/en/. Accessed 19 May 2020.

Latinopia (2020). Tenopia and Jt (2020). http://latinopia.com/. Accessed 2 Sept. 2020.

Latino Public Broadcasting (2020). http://lpbp.org/. Accessed 2 May 2019.

Las Marthas (2013). PBS Independent Lens. https://www.pbs.org/independentlens/films/las-marthas/. Accessed 30 Aug. 2020.

Me llamaban King Tiger. Bullock Texas History Museum (2019). https://www.thestoryoftexas.com/ visit/calendar/education/viva-cinema-me-llamaban-king-tiger-20180908. Accessed 26 Sept 2020.

Leen, Catherine. "From Don Juan to Dolores Huerta: Foundational Chicana/o Films." Routledge Handbook of Chicanalo Studies. Ed. Francisco A. Lomelí et al. Routledge, 2019. 207-10.

MACIEL, David R. El bandolero, el pocho y la raza: imágenes cinematográficas del chicano. Siglo XXI Editores, 2000.

Maciel, David R. "El florecimiento cultural chicano." NEXOS XL/490 (2018): 82-86. https://www. nexos.com.mx/?p=39479. Accessed 21 Sept. 2020.

Maciel, David R. La otra cara de México: Ensayos acerca del pueblo chicano. UNAM, 2018.

Maciel, David R. \& Susan Racho. "Yo soy chicano: La heroica y turbulenta vida de los chicanos en el cine y la televisión." La otra cara de México: Ensayos acerca del pueblo chicano. Ed. David Maciel. UNAM, 2018. 375-378. 
Morales, Sylvia. “Cómo se hizo 'La Chicana”" in La Opinión [Los Angeles] (Dec 16, 1980): 14.

Morales, Sylvia. “Filming a Chicana Documentary." In Somos [Mexico City] (March 1979): 7-16.

Nichols, Bill. Introduction to Documentary. $2^{\text {nd }}$ ed., Indiana UP, 1992.

Noriega, Chon A., ed. Chicanos and Film: Essays on Chicano Representation and Resistance. Garland, 1992.

Porvenir Massacre (2020). TSHA. https://www.tshaonline.org/handbook/entries/porvenir-massacre. Accessed 29 Sept. 2020.

Rosales, Francisco A. Chicano!: The History of the Mexican American Civil Rights Movement. Arte Público Press, 1996.

Stream Harvest Season (2020). PBS https://www.pbs.org/independentlens/films/harvest-season/. Accessed 27 Sept. 2020.

The Films and Videos of Lourdes Portillo (2016). Lourdes Portillo. https://www.lourdesportillo.com/ index.php. Accessed 31 Aug. 2020.

The Storm that Swept Mexico (2020) Latino Public Broadcasting. http://lpbp.org/programs/the-stormthat-swept-mexico/. Accessed 22 May 2020.

Trailer. The Pushouts. (2020) PBS SoCal https://www.pbssocal.org/programs/voces/preview-7qdpm7/. Accessed 27 Sept. 2020.

Treviño, Jesús Salvador. Eyewitness: A Filmmaker's Memoir of the Chicano Movement. Arte Público Press, 2001.

US. Census Bureau 2017. American Community Survey B03001 1-Year Estimates Hispanic or Latino Origin by Specific Origin. http://www.https.com//factfinder.census.gov/faces/ tableservices/jsf/pages/productview.xhtml?pid=ACS_17_1YR_B03001\&prodType=table. Accessed 2 May 2019.

Valdés, Luis. Lecture delivered at the Cineteca Nacional, Mexico City, August 10, 2014.

Zoot Suit Riots Gallery (2020). PBS. https://www.pbs.org/wgbh/americanexperience/features/zootsuit-riots-gallery/. Accessed 2 Sept. 2020.

Personal interviews

Artenstein, Isaac. Personal interview, 24 May 2000.

De los Santos, Nancy. Personal interview, 30 Jan. 2015.

Esparza, Moctezuma. Personal interview, 5 Oct. 52019.

Espinosa, Paul. Personal interview, 20 July 2019.

Espinosa, Paul. Personal interview, 13 Sept. 2020.

Estrada Soto, Angel. Personal interview, 8 July 2018.

Galán, Héctor. Personal interview, 11 Dec. 2016.

Galán, Héctor. Personal interview, 29 Aug. 292020.

Gutiérrez, Efraín. Personal interview, 3 Oct. 1998.

Ibarra, Cristina. Personal interview, 22 Sept. 2015.

Morales, Alejandro. Personal interview, 19 Apr. 2017. 
Ortiz, Luis. Personal interview, 18 Jan. 2019.

Portillo, Lourdes. Personal interview, 19 Dec. 2019.

Portillo, Lourdes. Personal interview, 11 Sept. 2020.

RaCho, Susan. Personal interview, 3 Mar. 2014.

Ruiz, José Luis. Personal interview, 12 July 1997.

Telles, Ray. Personal interview, 24 May 2014.

Tovares, Joseph. Personal interview.21 May 2014.

Treviño, Jesús Salvador. Personal interview, 31 Aug. 2020.

Treviño, Jesús Salvador. Personal interview, 14 Sept. 2020.

Simón, Laura Angélica. Personal interview, 2 June 1999. 
